\title{
Curriculum development and quality work in higher education in Sweden: The external stakeholder perspective
}

\author{
Per Fagrell, Anna Fahlgren, Svante Gunnarsson
}

\begin{abstract}
This article provides an external stakeholder perspective on the influence of higher education in Sweden, exploring their views on curriculum development and quality work at the programme level. Semi-structured interviews with a selected number of representatives of external stakeholders involved in various educational areas were conducted at seven higher education institutions. The participants argued that changes in their business sectors, and subsequent changes in the knowledge and skills in the labour needed, should encourage higher education institutions to adjust and develop their programmes. They did not anticipate or demand immediate changes in response to their comments, nor did they see themselves as a part of any quality assurance scheme. Uncertainties about the internal decision-making process and organisation in higher education institutions apparently do not facilitate external stakeholders' understanding of their role in the larger scheme. However, all informants had comments on quality in higher education, perceiving it predominantly as something connected to the world of work. The practical implication of this study is that curriculum development at higher education institutions would benefit from communicating the internal decision-making processes to external stakeholders and agreeing on the expectations with them, in collaboration.
\end{abstract}

Keywords: Curriculum development; quality; higher education; external stakeholder

Received 8 April 2020; revised version received 26 June 2020; accepted 2 July 2020. Corresponding author: Per Fagrell, KTH Royal Institute of Technology, Stockholm (perfag@kth.se).

\section{Introduction}

The involvement of external stakeholders in higher education takes various forms and modes and is often not firmly institutionalised (Thune, 2011). The scope and modes of collaboration between higher education institutions and business 1 are widely reported as being complex and multifaceted, due to the multitude of agents,

1 In this study, we include the whole labour market as business; that is, we include, for example, public hospitals and schools, as well as private business. 
activities, and different sets of goals (Anderson, 2001; Thune, 2011). Consequently, they are difficult to map and categorise, although attempts have been made (c.f. Bonaccorsi \& Piccaluga, 1994; Mora-Valentín, 2002).

Previous research on external stakeholders and their involvement in higher education, especially with regard to governance of higher education institutions and to quality assurance (Beerkens \& Udam, 2017; Leisyte \& Westerheijden, 2014; Magalhães, Veiga, \& Amaral, 2018; Musiał, 2010; Pinheiro, 2015; Rosa \& Teixeira, 2014), has often raised concerns about the involvement of external stakeholders in what are mainly seen as internal higher education matters. In fact, there have been calls for quality assurance for stakeholder relationships (Lyytinen et al., 2017), while others have labelled external stakeholders 'Trojan horses' or 'imaginary friends' (Magalhães et al., 2018; Rosa \& Teixeira, 2014). However, the voices of external stakeholders are rarely heard in this stream of literature. A rare exception is a study by Beerkens and Udam (2017), which shows that external and internal stakeholders have different expectations of quality assurance of higher education. Another example, and closer to curriculum development, is a study of industry advisory boards in engineering education (Genheimer \& Shehab, 2009). While the study by Genheimer and Shehab is set in the higher education system of the USA, it concludes that in order to be effective, the expectations of the advisory boards must be agreed upon by the involved stakeholders.

This study focuses on representatives of external stakeholders involved in permanent advisory boards or temporary working groups for curriculum development of new or existing higher education programmes. By exploring the attitudes and expectations of a selected number of external stakeholder representatives, a scarce external perspective is added to the discussion on stakeholder influence in higher education. The study addresses the following research questions: How do the external stakeholders perceive the educational collaboration in which they are involved? If provided an opportunity, what would the external stakeholders like to affect, and what are their main arguments for curriculum development? What are their views on quality and quality work in higher education?

Semi-structured interviews with representatives of external stakeholders at seven different educational programmes in seven higher education institutions in Sweden were conducted. In order to gain as much variety as possible from the interviews, a wide range of educational areas was selected: teacher training, nursing, biomedicine, engineering (x2), environment and health protection, and media and communication.

\section{External stakeholders' involvement in contemporary higher education}

There are many ways to define and identify stakeholders and stakeholder relationships in higher education (c.f. Benneworth \& Jongbloed, 2010; Kettunen, 2015; Mainardes, Alves, \& Raposo, 2012; Marshall, 2018). In this paper, we define 
future employers of graduates as stakeholders in higher education, separate from government and students, referring to them as external stakeholders. As stakeholders, employers are diverse, including individual businesses, industry organisations, professional bodies, and public organisations like schools and hospitals (Marshall, 2018). They are said to mainly be concerned with quality in terms of the result of higher education: the graduates (Harvey \& Knight, 1996). Since employment of graduates has a strong place in the political narrative of economic growth and the economic state of the country, employers have become one of the most significant stakeholders in the higher education system (Marshall, 2018). Using a framework for stakeholder analysis adopted by Mitchell, Agle, and Wood (1997), Marshall shows how the transition from elite education, through mass education, to a presumed future of universal education (Trow, 2000) changes stakeholder relationships. Marshall claims that in mass education mode, the employers are the definitive stakeholder (Mitchell et al., 1997, p. 878), with governments and students as two other strong stakeholders. However, Marshall notes that there are variants in different countries/regions in terms of the speed and conditions for the transition and thus also differences in the stakeholder relationships, and that status of employers as the definitive stakeholder may be particularly applicable in vocational sectors. With an example from engineering education, this argument is endorsed by Case (2017), who, by describing the historical evolution of engineering degrees and their stakeholders, argues that the introduction of the Washington Accord2 rendered engineering employers the most important stakeholder, supported by accreditation bodies such as ABET3, where employers have a strong influence (Lucena et al., 2008).

In Sweden, as in many other countries, a governmental agency conducts the external quality assurance and accreditation of higher education. The current national quality assurance scheme in Sweden, introduced in 2017, is based on the European Standards and Guidelines for Quality Assurance (ESG) (ENQA, 2015). However, the main objective of the current Swedish external quality assurance system is to evaluate the internal quality assurance process at each higher education institution (UKÄ, 2016).

The involvement of external stakeholders in the internal quality work is not mandated nor regulated by the state or by the national quality assurance agency. In fact, collaboration between higher education institutions and business is not mandated or regulated at the national level in Sweden other than by the representation of external stakeholders at the board level, where they have been in the majority since 1988 (Musial, 2010). However, in the appropriation directions from the Swedish government to every higher education institution, it is stated that higher education programmes offered at higher education institutions must meet the demands of students and the needs of the labour market. A Swedish governmental

\footnotetext{
2 The Washington Accord is an agreement between national bodies (initially of Anglophone countries but now extending beyond them) that perform the professional accreditation of engineers and engineering degrees to recognise one another's accreditations.

3 https://www.abet.org/ (Accessed 19 March 2020)
} 
committee, investigating the development of higher education over the last 20 years, reported that the demands of students were well satisfied but that there were doubts that the needs of the labour market were equally satisfied (SOU 2015:70, 2015 , pp. 241-250). The committee remarked that changes in the higher education system since 1993, have left an opportunity to collaborate with external stakeholders in education not yet fully used (SOU 2015:70, 2015, p. 244).

\section{Educational collaboration, curriculum development and quality work in higher education}

Previous research has reported that collaboration between universities and external stakeholders has traditionally taken place through informal agreements between companies and individual academics or institutions, and it can thus take varying forms and modes (Thune, 2011). Different traditions for educational cooperation in different business sectors, as well as in different educational areas, can explain the variations (Thune, 2011). Educational collaboration can roughly be divided into three main categories, the first of these is of particular interest in this study (Brandt et al., 2008): collaboration focused on

- creating new or revising existing programmes. This is mainly done through advisory committees/boards, where representatives of individual companies, trade associations, trade unions, and other organisations can make suggestions and comments on the content, structure, placement in time and space, teaching methods, examinations, and more.

- teaching and learning processes. This is mainly carried out through guest lectures, case studies, degree projects, external supervision, internships, and study visits.

- the transfer from study to working life. This occurs primarily through internships, degree projects, mentoring, recruitment fairs, career counselling.

To create or revise a programme puts the curriculum into the forefront. However, the curriculum as a concept is ambiguous and scholars have made several efforts to define it (c.f. Barnett \& Coate, 2005; Lattuca \& Stark, 2009). For example, Lattuca and Stark call the curriculum an academic plan, placed in a sociocultural context and influenced by different external and internal factors. The development of the curriculum has links to internal quality work and is thus sometimes called quality enhancement. In this article we prefer to use curriculum development. Curriculum development includes a) curriculum design - the design of university programmes, courses and related content, and b) curriculum delivery-the delivery of programmes and courses to students via a large range of mechanisms, such as lectures, student projects, and placements (Plewa, Galán-Muros, \& Davey, 2015, p. 36). Fundamental curriculum development can occur when a programme, an 
institution, or an educational system faces a crisis (Graham, 2012) or an 'external shock', such as the change from elite to mass higher education (Plate, 2012). Taking engineering education as an example again, the shift by the external accreditation body ABET from an input-based accreditation scheme to an outcome-based scheme in 1997 (Peterson, 1996) paved the way for a global shift in engineering curriculum development to a focus on intended learning outcomes at the programme level (Case, 2017). The aforementioned Washington Accord is an example of such an engine for curriculum development, predominant in Anglophone countries (Lucena et al., 2008), while the $\mathrm{CDIO}_{4}$ Initiative (Crawley et al., 2014; Edström, 2017) exemplifies a growing global curriculum reform movement in engineering education. The CDIO framework is tightly connected to quality development and quality assurance. The defining documents, the CDIO Syllabus and the CDIO Standards, enable systematic processes, for example, defining the expected learning outcomes, verification of the fulfilment of program goals, and program evaluation, as well as recommendations to engage stakeholder in the processes. One example of how the CDIO framework is used as an integrated part of a university's the quality system is presented in Gunnarsson, Herbertsson, and Örman (2019). The CDIO framework was originally designed for engineering education, but has in recent years been applied to other subject areas (Fahlgren et al., 2019; Malmqvist et al., 2016). It is worth mentioning that the CDIO framework was initiated from within higher education institutions, unlike the ABET criteria and the Bologna Process.

In Europe, as manifested through the Bologna Process during the last two decades, there has been a move towards increased knowledge transfer and innovation, as well as an increased expectation that higher education should better match the needs of the labour market (c.f. EHEA, 2015). Student mobility and employability have been two of the drivers for educational policy development in the Bologna Process. According to the ESG, external stakeholders should, for example, be involved in the design of study programmes (ESG 1.2) and in ongoing monitoring and periodic review of programmes (ESG 1.9), among other things (ENQA, 2015). Hence, the design of the quality assurance scheme imposes a relationship with external stakeholders and also implies a link to curriculum development, although the relationship between quality assurance and curriculum development is debated (Williams, 2016).

A model for quality assurance and quality enhancement, be it for a single programme or in a national context, or even in international context, relies on a definition of quality in higher education. Four themes emerge as the most commonly used concepts of quality in higher education: quality as exceptional, as purposeful, as accountable, and as transformative (Schindler et al., 2015). These themes, originally conceptualised in the 1990s (c.f. Green, 1994; Harvey \& Green, 1993; Harvey \& Knight, 1996), are consistent with newer publications on quality

${ }_{4}$ CDIO: Conceive-Design-Implement-Operate 
(Schindler et al., 2015). However, Schindler et al. claim that there is a trend in the recent literature towards stakeholder-driven definitions of quality.

Another way to approach quality is to divide it into quality characteristics, such as inputs, processes, and outputs (Udam \& Heidmets, 2013; Westerheijden, 2007). Inputs consist of, for example, admission requirements, academic staff qualifications and staff/student ratios; processes consist of, for example, educational objectives, study load, student support and feedback procedures for students' and alumni's experiences; and outputs consist of, for example, graduates' knowledge and skills, graduation rates/drop-outs, and time to degree and employment rates. This division could facilitate an understanding of the whys and wherefores of different stakeholder groups' focus on different aspects of quality.

In earlier research about higher education institutions as organisations, quality has been identified as a conveyor for change (c.f. Stensaker, 2004); in fact, 'quality assurance has proven to be the most potent of change agents' (Kogan \& Hanney, 2000, p. 240). In new institutional theory, organisational imitation has often been described as a way for organisations to respond to external (or internal) pressure for change, giving rise to the concept of isomorphism (DiMaggio \& Powell, 1983). However, studies have shown that external ideas are not absorbed straight into the organisation, the change process is dynamic in that external demands are 'translated' by internal actors, and given a local meaning. Furthermore, similar external pressures can still yield different responses due to different internal structures and traditions in the organisations - in this case the higher education institutions (Karlsson et al., 2014). The higher education institution can be fully aware of the external context and expectations, but still be focused on internal developments (Harvey \& Stensaker, 2008).

This brief review of educational collaboration, curriculum development, and quality work, as well as stakeholders in higher education, forms the background to this exploratory study, helping to conceptualise the empirical findings.

\section{Method}

This is a qualitative exploratory study of seven examples of educational collaboration. In seven different programmes, each from a different Swedish higher education institution, semi-structured interviews were conducted with representatives of external stakeholders to obtain information about their experiences and expectations of the collaborations. The qualitative interview approach was chosen as suitable to understand the world from the informants' point of view (Kvale \& Brinkmann, 2009). Furthermore, the exploratory approach was chosen because previous research indicated little knowledge about external stakeholders' view on the topic; thus, an exploratory approach would help us to unfold, explore, and possibly frame the phenomenon under study as well as prepare for future, more comprehensive studies (Patton, 2002). One educational programme at each higher education institution (henceforth called a 'case') was selected using 
a purposeful sampling method (Cohen, Manion, \& Morrison, 2011) with the intention of obtaining a rich variety of cases and thereby meeting the goals of the study's explorative approach. With a purposeful/snowball sampling method (Cohen et al., 2011), mainly assisted by programme management, the external stakeholder representatives were selected. The selected informants were typically involved in permanent advisory boards or temporary working groups for curriculum development of new or existing programmes. In total, seven semi-structured interviews with eleven representatives of external stakeholders were conducted, varying in length from 50 to 70 minutes. All interviews were transcribed verbatim and then coded and analysed using the software tool NVivo. See Table 1 for a brief overview of the cases.

\begin{tabular}{lllll}
\hline $\begin{array}{l}\text { Higher } \\
\text { education } \\
\text { institution }\end{array}$ & $\begin{array}{l}\text { Programme/ } \\
\text { educational area }\end{array}$ & Level & $\begin{array}{l}\text { Number of } \\
\text { informants }\end{array}$ & Description of informant(s) \\
\hline 1 & Teacher training & $\begin{array}{l}\text { Bachelor/ } \\
\text { Vocational }\end{array}$ & Two & Course mentor \\
\hline 2 & $\begin{array}{l}\text { Media and } \\
\text { Communication }\end{array}$ & $\begin{array}{l}\text { Bachelor \& } \\
\text { Master }\end{array}$ & Two & Advisory board members \\
\hline 3 & Nursing & $\begin{array}{l}\text { Bachelor/ } \\
\text { Vocational }\end{array}$ & One & Advisory board member \\
\hline 4 & Engineering & $\begin{array}{l}\text { Master/ } \\
\text { Vocational }\end{array}$ & Two & $\begin{array}{l}\text { Advisory board/programme } \\
\text { management members }\end{array}$ \\
\hline 5 & Engineering & $\begin{array}{l}\text { Master/ } \\
\text { Vocational }\end{array}$ & One & Advisory board member \\
\hline 6 & $\begin{array}{l}\text { Environment \& } \\
\text { Health Protection }\end{array}$ & One & Advisory board member \\
\hline 7 & Biomedicine & $\begin{array}{l}\text { Bachelor \& } \\
\text { Master }\end{array}$ & Two & Alumni network members \\
\hline
\end{tabular}

Table 1. Overview of cases

The interviews were thematically analysed (Clarke \& Braun, 2017), initially in a quasi-deductive manner, following Patton (2002, p. 453). Thus, we began the coding procedure by using the overarching themes from the interview guide as themes. This was followed by an inductive and data-driven analysis (Cohen et al., 2011) based on the responses from the interviews.

We have deliberately not interviewed programme management or collected and analysed internal documents or other detailed information about the different programmes because we wanted to focus on the external stakeholders' views. However, we have collected information about the selected programmes before the interviews in order to provide an overview of each case. 


\section{Seven cases of external stakeholder involvement}

The seven cases are different in several respects, such as tangible differences in educational area, educational level, and institutional setting, as shown in Table 1. The external stakeholders are involved in different 'functions', or 'groups', as we will call them henceforth. Many of the groups are associated with programmes that have been running for years and can be labelled as permanent, while some of the groups were created primarily for the purpose of supporting the higher education institution when it prepared to establish a new programme or conduct a major revision of an existing programme. In such cases, there were uncertainties about the status of the group when the new (or newly revised) programme started to run. In fact, in one case, the group had not met since the new programme started, about two years before the interview, leading the interviewee to suspect that the group no longer existed. The frequency of meetings also differed between the two types of groups; in the permanent groups, one or two meetings per semester seemed to be standard, whereas for temporary groups the frequency of the meetings could be both higher and more ad hoc.

We found no standardised form of recruitment onto the programmes for the representatives of the external stakeholders. Most often, it was the employer, a company or a public administration that had been asked to participate in the group, and the individual was appointed by the employer to fulfil the request. In several cases, the person appointed was also a graduate of the institution. When the group was permanent or existed mainly due to a shared and formal agreement on work placements (in nursing, for example), the employer had a taken-for-granted place in the group, and the person holding that place today had sometimes inherited it and would pass it on when and if he or she changed job position. In our material, course mentors in a teacher training programme constitute a special case. These mentors are recruited through ordinary job advertisements and are employed part-time (10$20 \%$ ) by the university while still working as teachers in elementary schools. They function as boundary spanners between the university and the future employer, compulsory schools in Sweden. They are involved in teaching at the university, meeting students, monitoring and developing teacher training courses, and meeting university teachers. This is the only case in which we noticed a direct cost for the external stakeholders and their involvement in higher education.

In most cases, the external stakeholders have a degree of freedom that allows them to ensure internships for students, guest lecturers, plant visits, and so on. However, they often express self-criticism with regard to the way they bring back information and other news to the 'home' organisation and realise that there is potential for improvement in this respect.

The groups can consist of external stakeholders only or external stakeholders and a few teachers from the programme. In some cases, there are also student representatives in the groups. However, the main contact at the higher education institution, in many cases the only contact, is the programme management that runs the group and its meetings. Because the internal organisation 
at higher education institutions in Sweden varies, the responsibilities and abilities to make decisions for programme management differ from case to case. We explicitly asked the external stakeholders about the possibilities or limitations for the group and/or programme management to make decisions, although we did not cross-check this with the programme management. The answers revealed that the external stakeholders are aware that their primary task is to give advice and decision support; they are not concerned whether any decisions are made within the group, by the programme management or somewhere else. Several of the interviewees recognised that the internal decision-making process universities can be long and winding:

I think he [the programme director] has to go higher [in the organisation], because there are these rules and regulations about who should [...] well, what position people have at the university. (Case 2, informant \#4)

In the same interview, a moment later, the other participant observed, 'Well, my picture of it is that it takes a long time, overall, I mean everywhere at the university' (Case 2, informant \#3).

All the interviewees felt that their opinions are sought out by the programme management and the university: 'I don't expect them [the university] to change everything just because I express new ideas, but I really feel that they listen' (Case 2, Informant \#3).

Although the expectations of immediate decisions or changes are low, there is an expectation of feedback and of seeing some kind of progression from one meeting to another. In some cases, especially those centred on the creation of a new programme or revision of an existing programme, the mission for the group is clearly stated by the university and understood by the external stakeholders. However, in the cases with permanent advisory boards, the external stakeholders cannot identify the mission of the group. There may be a mission for the group in those cases, but the external stakeholders cannot explain it. To conclude, the expectations of what the groups can or cannot achieve have apparently not been discussed and agreed upon within the groups. Furthermore, the internal decisionmaking processes at higher education institutions are mainly unknown to the external stakeholders in this study.

\section{External stakeholders' take on the development of higher education programmes}

The second research question for the study asked what external stakeholders would like to affect and what arguments they use for curriculum development. An initial finding of the study was that in their perception of the intentions of programmes and the arguments they use for curriculum development, the external stakeholders 
do not separate vocational degrees from general degrees. Furthermore, the agendas of the meetings in the groups usually guide the way things can be said and done. For example, in one or two groups, the focus is almost entirely on the mandatory periods of work placements for the students and how to organise, monitor, and evaluate these. Any discussion about the regular courses in the programme and how to develop these or the whole programme are very much secondary topics, if they arise at all within the group.

In the other cases, the focus in the groups seems to centre on ways to improve the programmes. One issue that frequently arose in the interviews is the external stakeholders' ambition to communicate recent or ongoing changes in their sector. For example, in relation to environmental and health protection, local governments are facing a changing mission whereby they are now supposed to be proactive and preventive in order to help clients (also a new concept) to self-monitor legal obligations. This shift demands the development of the profession and hence the corresponding programme:

Then the students need to understand the big differences all these new laws induce. The EU legislation, as well as our own environmental law, both are now more proactive. And call for self-evaluation. (Case 6, Informant \#9)

Furthermore, in the case of the biomedicine programme, the rapid development in the sector was emphasised by both interviewees:

This issue with us [the sector] going from small molecules to biologics [large molecules], is such a big shift in how to think about treatments and pharmaceuticals that it would be a pity if such a large [educational] programme missed it. (Case 7, Informant \#11)

Another theme in the messages by the external stakeholders is the desirable knowledge and skills in new graduates for them to succeed in the labour market. In these discussions, the external stakeholders referred to the experiences of new graduates as much as, or even more than, information about the present curriculum. Overall, the dominant message from external stakeholders concerns the students' career opportunities, though not only for their first position after graduation. This was expressed in different ways, such as 'We want the university to foster curiosity, an ability to deliver [...] but also systems thinking' (Case 4, Informant \#7) and 'We want students with more practical understanding' (Case 5, Informant \#8). We interpret the 'we' in the quotes above and elsewhere in the interviews mostly to refer to the sector, including, but not exclusively, the participants' own companies/organisations. In the end, the messages always relate to the demand for labour and/or new knowledge coming from the university and onto the labour market. 


\section{External stakeholders' views on quality and quality work in higher education}

In the discussion of quality, an initial but important finding from the interviews was that, regardless of educational context, none of the external stakeholders see themselves as part of the internal quality process at the higher education institution. As the empirical material is only from the external stakeholders, we do not know the view on this of the programme management and the higher education institution. However, the external stakeholders all made comments on quality in higher education, obviously related to the programmes in which they are involved. The overarching theme in these discussions was quality perceived as something connected to the world of work. This focus on the output of the programme was balanced with comments about quality in the processes, such as the view that modern learning environments are a quality indicator. One more process indicator that was raised concerned the teachers:

Well, I think, hmm [...] that it [quality] is a combination of skilled teachers and competence in that area; I mean, both subject-related and pedagogically skilled. But also enthusiasm and dedication, which is also important for good quality, and that they have [...] they feel a big responsibility for their courses, to revise them and keep them up to date and such. (Case 7, Informant \#10)

The idea that there can be differences in views on quality between external stakeholders and higher education institutions was recognised in the interviews, such as the idea that a programme can be of good quality for those students who want to pursue further studies at the university while being less good for a career outside academia. The following quote shows the other side:

Interviewer: So, is it an interpretation [of what you said earlier] that a programme has good quality if it prepares [students] for the profession?

Case 6, Informant \#9: Yes, in my view it is. But, as I said, that does not necessarily mean that it has good academic quality.

There is a telling example of the difference in views on quality between academia and employers in one of the cases. One employer found the quality (in their view) of the graduates to be too low for the intended work situation. They have therefore established a 'first year of practice' for their new graduates, including mandatory lectures and seminars, as well as practical learning moments. Paradoxically, this 'first year of practice' has received criticism from the university in terms of the low quality of the lectures. 


\section{Concluding discussion}

To sum up the findings of this study: we received similar comments on several topics, despite the variation in cases. For example, independently of the educational context, the expectations, comments, and arguments from the external stakeholders were similar. The external stakeholders want to send messages to higher education institutions about changes in their business sectors, and about the subsequent changes in expected knowledge and skills, in order to encourage the higher education institutions to adjust and develop their programmes. The external stakeholders do not expect immediate changes as a result of their comments, and they realise that their task is to give advice to a sometimes long internal decisionmaking process at the higher education institution. Neither do they see themselves as a part of an internal quality assurance scheme at the higher education institution, although all have comments on quality in higher education, predominantly as something connected to the world of work.

This might be interpreted merely as different ways for external stakeholders - employers - to make sure that the higher education programmes can deliver the right competence. In reality, the messages from the external stakeholders centre mainly, but not exclusively, on employability and the intended establishment of the knowledge and skills necessary for students to obtain a future position in the business sector. In terms of quality in higher education, understood in terms of inputs, processes, and outputs (Udam \& Heidmets, 2013), the external stakeholders seem to value a programme for its output, the students, rather than its input, the curriculum. In fact, anything else would have been more of a surprise because the legitimacy of the external stakeholders emanates from their up-to-date knowledge about the labour market in their sector and not from their proficiency in internal higher education matters.

However, as we have shown, in most of the cases, the external stakeholders have a broader perspective for graduate students that goes beyond their first position following graduation and posts at the stakeholders' own company or organisation. The messages about profound changes in their sector, about long-term career opportunities and about soft skills, such as curiosity, suggest that the external stakeholders see themselves as representatives for something more than their own company or organisation.

The fact that the external stakeholders do not see themselves as a part of an internal quality work process at the higher education institution is a bit of a surprise. It could be that they are in fact a part of the internal quality scheme but that this has not been communicated to the external stakeholders interviewed in this study. The comments from the external stakeholders about quality and their perception that academia and employers may value quality differently is a topic for further research. Different stakeholders' takes on the definition of quality may help to 
explain the scepticism about the involvement of external stakeholders in higher education, as mentioned in the introduction.

The external stakeholders in this study do not expect immediate change as a result of their input; rather, they see their input as advice. However, they all expect some feedback on how their comments and advice have been received. There is also respect for the internal decision process at the higher education institution, even if it is often a much slower process than in their home organisation, sometimes 'stunningly slow', as one informant put it. Earlier research on how external pressure for change must be 'translated' by internal actors in order to give it local meaning (Harvey \& Stensaker, 2008; Karlsson et al., 2014) may help to explain the slow process.

Uncertainties about the internal decision-making process and organisation at the higher education institutions do not appear to help the external stakeholders to understand what their role is in the bigger scheme. Because the external stakeholders do not have full insight into the internal decision-making process at the higher education institutions, they do not have the tools to increase the necessary external pressure for change; hence, they cannot become the definitive stakeholders in higher education today, as Marshall (2018) suggests. However, this assertion needs more research than this exploratory study can provide. For example, an indepth study to identify situations in which ideas from external stakeholders really have an impact on higher education and its institutions today would complement this study. That said, a study with a focus on different ways for higher education programmes to either embrace or protect themselves from external pressure would also be interesting. The practical implication of this study, albeit exploratory with a rather small sample, is that higher education institutions would benefit from communicating their internal decision-making processes to external stakeholders and mutually agree on the expectations of the collaborations, in order to develop the curriculum more effectively.

\section{Acknowledgements}

The study is a part of the MERUT project, externally funded by Vinnova, a Swedish government funding agency. 


\section{Author biographies}

Per Fagrell is a PhD student at the Department of Learning in Engineering Sciences at KTH Royal Institute of Technology, Stockholm, Sweden. His main research interest is the role of external stakeholders in the development of engineering education.

Anna Fahlgren is an Associate Professor in Regenerative Medicine at Linköping University. Her main research interest is experimental orthopaedics. She is also program manager for a new BSc program in Industrial and Experimental Biomedicine where she has transferred and used the CDIO Syllabus on a subject outside of engineering.

Svante Gunnarsson is Professor in Automatic Control at the Department of Electrical Engineering, Linköping University, Sweden. His main research interests are modeling, system identification, and control of industrial robots. For many years he was chairman of the Program Board for education programs in Electrical Engineering, Physics, and Mathematics at Linköping University, including the engineering program in Applied Physics and Electrical Engineering. Since the start, he has had a leading role in the CDIO Initiative, a worldwide innovative educational framework for developing the next generation of engineers. 


\section{References}

Anderson, M. S. (2001). The complex relations between the academy and industry: Views from the literature. The Journal of Higher Education, 72(2), 226246. doi: $10.2307 / 2649323$

Barnett, R., \& Coate, K. (2005). Engaging the curriculum in higher education. Maidenhead: Open University Press.

Beerkens, M., \& Udam, M. (2017). Stakeholders in higher education quality assurance: Richness in diversity? Higher Education Policy, 30(3), 341-359. doi:10.1057/s41307-016-0032-6

Benneworth, P., \& Jongbloed, B. W. (2010). Who matters to universities? A stakeholder perspective on humanities, arts and social sciences valorisation. Higher Education, 59(5), 567-588. doi:10.1007/s10734-009-9265-2

Bonaccorsi, A., \& Piccaluga, A. (1994). A theoretical framework for the evaluation of university-industry relationships. $R \& D$ Management, 24(3), 229-247.

Brandt, E., Dæhlen, M., Hagen, A., Hertzberg, D., Kaloudis, A., Seip, Å. A., . . . Vabø, A. (2008). Effekter av samarbeid mellom høyere utdanning og arbeidsliv-en forstudie. Oslo: Fafo.

Case, J. M. (2017). The historical evolution of engineering degrees: Competing stakeholders, contestation over ideas, and coherence across national borders. European Journal of Engineering Education, 42(6), 974-986. doi:10.1080/03043797.2016.1238446

Clarke, V., \& Braun, V. (2017). Thematic analysis. The Journal of Positive Psychology, 12(3), 297-298. doi:10.1080/17439760.2016.1262613

Cohen, L., Manion, L., \& Morrison, K. (2011). Research methods in education (7th ed.). Abingdon: Routledge.

Crawley, E. F., Malmqvist, J., Östlund, S., Brodeur, D. R., \& Edström, K. (2014). Rethinking engineering education: The CDIO approach (2nd ed.). Cham: Springer..

DiMaggio, P. J., \& Powell, W. W. (1983). The iron cage revisited: Institutional isomorphism and collective rationality in organizational fields. American Sociological Review, 48(2), 147-160. doi:10.2307/2095101

Edström, K. (2017). Exploring the dual nature of engineering education: Opportunities and challenges in integrating the academic and professional aspects in the curriculum. (Doctoral), Kungliga Tekniska högskolan, Stockholm. (TRITA-ECE 2017:2)

European Association for Quality Assurance in Higher Education (ENQA). (2015). Standards and guidelines for quality assurance in the European higher education area (ESG). Brussels: EURASHE

European Higher Education Area (EHEA). (2015). The Bologna Process revisited: The future of the European higher education area. Retrieved 2020-03-17 from

http://www.ehea.info/media.ehea.info/file/2015_Yerevan/71/1/Bologna_P rocess_Revisited_Future_of_the_EHEA_Final_613711.pdf 
Fahlgren, A., Larsson, M., Lindahl, M., Thorsell, A., Kågedal, K., \& Gunnarsson, S. (2019). Design and outcome of a CDIO Syllabus survey for a biomedicine program. Paper presented at the 15th International CDIO Conference, Aarhus University, Denmark.

Genheimer, S. R., \& Shehab, R. L. (2009). A survey of industry advisory board operation and effectiveness in engineering education. Journal of Engineering Education, 98(2), 169-180. doi:10.1002/j.2168-9830.2009.tb01015.x

Graham, R. (2012). Achieving excellence in engineering education: The ingredients of successful change. London: The Royal Academy of Engineering.

Green, D. (Ed.). (1994). What is quality in higher education? London: SRHE \& Open University Press.

Gunnarsson, S., Herbertsson, H., \& Örman, H. (2019). Using course and program matrices as components in a quality assurance system. Paper presented at the The 15th International CDIO Conference, Aarhus University.

Harvey, L., \& Green, D. (1993). Defining quality. Assessment \& Evaluation in Higher Education, 18(1), 9-34.

Harvey, L., \& Knight, P. T. (1996). Transforming higher education. London: SRHE $\&$ Open University Press.

Harvey, L., \& Stensaker, B. (2008). Quality culture: Understandings, boundaries and linkages. European Journal of Education, 43(4), 427-442. doi:10.1111/j.1465-3435.2008.00367.x

Karlsson, S., Fogelberg, K., Kettis, Å., Lindgren, S., Sandoff, M., \& Geschwind, L. (2014). Not just another evaluation: A comparative study of four educational quality projects at Swedish universities. Tertiary Education and Management, 20(3), 239-251. doi:10.1080/13583883.2014.932832

Kettunen, J. (2015). Stakeholder relationships in higher education. Tertiary Education and Management, 21(1), 56-65. doi:10.1080/13583883.2014.997277

Kogan, M., \& Hanney, S. (2000). Reforming higher education. London and Philadelphia: Jessica Kingsley.

Kvale, S., \& Brinkmann, S. (2009). Interviews: Learning the craft of qualitative research interviewing. London: Sage.

Lattuca, L. R., \& Stark, J. S. (2009). Shaping the college curriculum: Academic plans in context. ( 2 nd ed.). San Francisco: John Wiley \& Sons.

Leisyte, L., \& Westerheijden, D. (2014). Stakeholders and quality assurance in higher education. In H. Eggins (Ed.), Drivers and barriers to achieving quality in higher education (pp. 83-97). Rotterdam: Sense.

Lucena, J., Downey, G., Jesiek, B., \& Elber, S. (2008). Competencies beyond countries: The reorganization of engineering education in the United States, Europe, and Latin America. Journal of Engineering Education, 97(4), 433447. doi:10.1002/j.2168-9830.2008.tb00991.x

Lyytinen, A., Kohtamäki, V., Kivistö, J., Pekkola, E., \& Hölttä, S. (2017). Scenarios of quality assurance of stakeholder relationships in Finnish higher 
education institutions. Quality in Higher Education, 23(1), 35-49. doi:10.1080/13538322.2017.1294410

Magalhães, A., Veiga, A., \& Amaral, A. (2018). The changing role of external stakeholders: From imaginary friends to effective actors or non-interfering friends. Studies in Higher Education, 43(4), 737-753. doi:10.1080/03075079.2016.1196354

Mainardes, E. W., Alves, H., \& Raposo, M. (2012). A model for stakeholder classification and stakeholder relationships. Management Decision, 50(10), 1861-1879. doi:10.1108/00251741211279648

Malmqvist, J., Huay, H. L.-W. K., Kontio, J., \& Minh, T. D. T. (2016). Application of CDIO in non-engineering programmes: Motives, implementation and experiences. Paper presented at the 12th International CDIO Conference, Turku University of Applied Sciences, Finland.

Marshall, S. J. (2018). Shaping the university of the future. Dordrecht: Springer.

Mitchell, R. K., Agle, B. R., \& Wood, D. J. (1997). Toward a theory of stakeholder identification and salience: Defining the principle of who and what really counts. The Academy of Management Review, 22(4), 853-886. doi:10.2307/259247

Mora-Valentín, E. M. (2002). A theoretical review of co-operative relationships between firms and universities. Science and Public Policy, 29(1), 37-46. doi: $10.3152 / 147154302781781146$

Musiał, K. (2010). Redefining external stakeholders in Nordic higher education. Tertiary Education and Management, 16(1), 45-60. doi:10.1080/13583881003629822

Patton, M. Q. (2002). Qualitative research \& evaluation methods (3rd ed.). London: Sage.

Peterson, G. D. (1996). Engineering criteria 2001: The ABET vision for change. JOM, 48(9), 12-14. doi:10.1007/BF03223065

Pinheiro, R. (2015). The role of internal and external stakeholders. In S. Schwartzman, R. Pinheiro, \& P. Pillay (Eds.), Higher education in the BRICS countries (pp. 43-57). Dordrecht: Springer.

Plate, R. (2012). The evolution of curriculum development in the context of increasing social and environmental complexity. Creative Education, 3(8), 1311-1319. doi:10.4236/ce.2012.38192

Plewa, C., Galán-Muros, V., \& Davey, T. (2015). Engaging business in curriculum design and delivery: A higher education institution perspective. Higher Education, 70(1), 35-53. doi:10.1007/s10734-014-9822-1

Rosa, M. J., \& Teixeira, P. (2014). Policy reforms, Trojan horses, and imaginary friends: The role of external stakeholders in internal quality assurance systems. Higher Education Policy, 27(2), 219-237. doi:10.1057/hep.2013.20

Schindler, L., Puls-Elvidge, S., Welzant, H., \& Crawford, L. (2015). Definitions of quality in higher education: A synthesis of the literature. Higher Learning Research Communications, 5(3), 3-13. 
Statens offentliga utredningar (SOU). (2015). Högre utbildning under tjugo år [Higher education during twenty years], SOU 2015:70. Stockholm: Fritzes.

Stensaker, B. (2004). The transformation of organisational identities: Interpretations of policies concerning the quality of teaching and learning in Norwegian higher education. (Doctoral), University of Twente, Enschede.

Swedish Higher Education Authority (UKÄ). (2016). National system for quality assurance of higher education. Stockholm: UK̈̈.

Thune, T. (2011). Success factors in higher education-industry collaboration: A case study of collaboration in the engineering field. Tertiary Education and Management, 17(1), 31-50. doi:10.1080/13583883.2011.552627

Trow, M. (2000). From mass higher education to universal access: The American advantage. Minerva, 37(4), 303-328.

Udam, M., \& Heidmets, M. (2013). Conflicting views on quality: Interpretations of 'a good university' by representatives of the state, the market and academia. Quality in Higher Education, 19(2), 210-224. doi:10.1080/13538322.2013.774805

Westerheijden, D. F. (2007). States and Europe and quality of higher education. In D. F. Westerheijden, B. Stensaker, \& M. J. Rosa (Eds.), Quality assurance in higher education: Trends in regulation, translation and transformation (pp. 73-95). Dordrecht: Springer Netherlands.

Williams, J. (2016). Quality assurance and quality enhancement: Is there a relationship? Quality in Higher Education, 22(2), 97-102. doi:10.1080/13538322.2016.1227207 